\title{
A INDENIZAÇÃO DA VÍTIMA NO JUÍZO CÍVEL COM BASE EM SENTENÇA PENAL CONDENATÓRIA TRANSITADA EM JULGADO
}

\author{
Luiz Gustavo Lovato ${ }^{1}$
}

Resumo: $O$ processo criminal tem por escopo principal a punição do agente que pratica um crime. Por punição a lei prevê a privação de liberdade, a restrição de direitos e a multa, todos cumpridos perante o Estado. A reparação ou compensação do dano sofrido pela vítima é um efeito secundário da condenação penal, que lhe permite não mais discutir esse direito, mas executar diretamente $o$ seu crédito em face do condenado. A participação da vítima do processo criminal, porém, é mínima, resumindo-se ao depoimento. Ela não tem espaço para requerer a condenação do réu a lhe indenizar e, menos ainda, produzir provas relacionadas à extensão do dano sofrido. Com base nesses problemas, a execução direta da sentença penal condenatória transitada em julgado, sem a necessidade de liquidação prévia no cível, torna-se cada vez mais difícil de ser realizada. Quiçá impossível.

Palavras-chave: Responsabilidade civil. Indenização. Sentença penal condenatória

\section{INTRODUÇÃO}

O Poder Judiciário, representante da essência do Poder do Estado no que tange à possibilidade de proferir decisões impo-

1 Mestre em Direito.Advogado e professor de Cursos de Graduação e Pós-graduação em Direito. E-mail: lovato@lovatoeport.com.br 
sitivas e definitivas em face do jurisdicionado, vive, nos dias atuais, uma notória crise de eficácia. A busca pelo bem da vida, máxima do Direito Processual, torna-se uma tarefa muita vezes inglória, fulminada pela ineficiência dos meios processuais atrelada à má-fé daqueles que veem nesta uma porta para a irresponsabilidade.

Se a autotutela é tipificada como crime, denominada exercício arbitrário das próprias razões de direito no art. 345 do Código Penal (CP), ou abuso de poder no art. 350 do mesmo diploma legal, a busca pela tutela jurisdicional torna-se não apenas um dever e um direito fundamental do cidadão, mas, principalmente, um dever de garantia por parte do Estado. As contendas devem ser resolvidas a fim de se buscar a paz e a harmonia sociais, mesmo que de forma impositiva.

O direito de ação está previsto no art. 5\%. da Constituição da República Federativa do Brasil (CRFB), em seus incisos XXXIV e XXXV, mas não constitui um pilar de sustentação solitário do Estado Democrático de Direito. Principalmente nos dias atuais, em que as concepções de um Estado Liberal se encontram cada vez mais distantes da realidade brasileira. $\mathrm{O}$ Estado Liberal não foi recepcionado pela CRFB, mas continua presente na obsoleta norma processual vigente, em conjunto com interpretações desconexas dos tribunais pátrios.

$\mathrm{O}$ direito fundamental do cidadão não vale de per si. Ele sobrevive em um contexto coletivo que se justifica pelo atual modelo de Estado Social e seu tão pouco lembrado art. $6^{\circ}$ da CRFB, que estabelece, de maneira inequívoca, serem "direitos sociais a educação, a saúde, a alimentação, o trabalho, a moradia, o lazer, a segurança, a previdência social, a proteção à maternidade e à infância, a assistência aos desamparados, na forma desta Constituição.”

Como preza a norma constitucional, se tratam de comandos abertos, passíveis de interpretação. Afinal, a assistência aos desamparados significa que não apenas aquele que não tem condições de se autogovernar merece assistência, mas 
aquele que depende da tutela do Estado para conferir a si o postulado normativo da dignidade da pessoa humana também.

Nesse sentido, Paulo Bonavides diz que o atual modelo de Estado Social cria uma situação de dependência do indivíduo em relação às prestações do Estado, fazendo com que este "cumpra a tarefa igualitária e distributivista, sem a qual não haverá democracia nem liberdade" ${ }^{2}$. A "igualdade niveladora", preconizada pelo autor, prevê a isonomia material como pilar da pacificação social, tratando desigualmente os desiguais e, mais, atuando "mediante intervenções de retificação na ordem social a remover as mais profundas e perturbadoras injustiças sociais"3.

Esses direitos sociais definem a necessidade de o Estado prestar ações afirmativas, desvinculadas do pleito clássico que exige petição inicial para que exista processo, e pedido para que exista tutela ${ }^{4}$. O pedido, então formulado pelo titular do direito, somente pode ser realizado pelo próprio titular ou por quem tenha poderes de representação em caráter extraordinário, como o Ministério Público, por exemplo.

Tanto o é que, mesmo em casos especiais de incapaz, réu preso ou revel, cabe o magistrado a nomeação de curador especial para administrar seus interesses, sob pena de nulidade do processo $^{5}$. A atuação do Ministério Público na defesa de interesses privados encontra limitações mesmo em casos de intervenção ministerial obrigatória.

Já entendeu o Superior Tribunal de Justiça (STJ) que, havendo no processo a disputa de interesses exclusivamente privados das partes, esses não configuram interesse público e, mesmo tratando-se de enquadramento na expressa norma processual que prevê a obrigatoriedade da intervenção ministe-

2 BONAVIDES, Paulo. Curso de Direito Constitucional. 13. ed. 2. tiragem. São Paulo: Malheiros, 2003, pp. 378/9.

3 ibidem.

4 O princípio da inércia ou demanda, previsto no art. $2^{\circ}$ do Código de Processo Civil (CPC) faz coro com a congruência dos arts. 128 e 460 do mesmo diploma legal, definindo a necessidade de não apenas a peça vestibular mas, especificamente, o pedido para que haja a prestação da tutela jurisdicional.

5 Cf. art. $9^{\circ}$ do CPC. 
rial quando a lide envolver direitos de incapazes ${ }^{6}$, a declaração da nulidade absoluta do processo depende da prova do prejuízo das partes, a ser realizada pelo próprio MP7.

Assim, se o MP pleitear a nulidade de um processo sob a alegação de que sua intervenção obrigatória não fora respeitada em face da existência de incapazes em um dos polos da demanda, deverá ele - o MP - provar que sua ausência trouxe prejuízo ao incapaz. Ou o processo não padecerá de nulidade, mesmo havendo cominação legal expressa prevendo-a.

No relatório do voto em questão, cinge-se o argumento que autoriza o julgado nessa parte (in verbis):

3. Quanto ao segundo argumento, no tocante à nulidade do acórdão no pertinente à não intervenção do Ministério Público para fins de preservação de interesse de incapaz, a jurisprudência desta Corte já assentou entendimento no sentido de que a ausência de intimação do Ministério Público, por si só, não enseja a decretação de nulidade do julgado, a não ser que se demonstre o efetivo prejuízo para as partes ou para a apuração da verdade substancial da controvérsia jurídica, à luz do princípio pas de nullités sans grief. Até mesmo nas hipóteses em que a intervenção do Parquet é obrigatória, como no presente caso em que envolve interesse de incapaz, seria necessária a demonstração de prejuízo deste para que se reconheça a nulidade processual. (Precedentes: REsp 1.010.521/PE, Rel. Min. Sidnei Beneti, Terceira Turma, julgado em 26.10.2010, DJe 9.11.2010; REsp 814.479/RS, Rel. Min. Mauro Campbell Marques, Segunda Turma, julgado em 2.12.2010, DJe 14.12.2010).

4. Na espécie, o Ministério Público não demonstrou ou mesmo aventou a ocorrência de algum prejuízo que legitimasse sua intervenção. Ao revés, simplesmente pretende, por intermédio do recurso especial, delimitar absoluto interesse interveniente

6 Cf. art. 82, I do CPC.

7 REsp 818978. STJ, $2^{\mathrm{a}}$ Turma, Rel. Min. Mauro Campbell Marques, DJe 18.11.2011. 
sem que indique fato ou dado concreto ou mesmo hipotético que sustente tal legitimidade. O prejuízo aqui tratado não pode ser presumido; precisa ser efetivamente demonstrado, o que não se deu no caso dos autos.

O Ministério Público tem sua atuação cada vez mais adequada à preservação dos interesses metaindividuais ou transindividuais, não lhe cabendo, seja por questão de legitimidade ou estrutura, intervir em todas as contendas que tratem de interesses privados. Mesmo que envolvam incapazes. Assim já preconiza o caput do art. $1^{\circ}$. da Lei Orgânica do Ministério Público ${ }^{8}$.

Os interesses individuais podem estar relacionados com outros iguais, homogêneos, e possuírem um caráter metaindividual, quando decorrerem de uma origem comum ${ }^{9}$. Mas, para que legitimem o MP a atuar representando os interessados, deverão ser protagonizados em ações de caráter coletivo, como a Ação Civil Pública, por exemplo.

Some-se as máximas apresentadas às regras gerais de competência e tem-se, com a redação do inciso IV do art. 387 do Código de Processo Penal, uma exceção à regra de que a competência em razão da matéria será sempre de caráter absoluto. Isso porque a norma em questão autoriza o juiz criminal a, na sentença penal condenatória, fixar "valor mínimo para reparação dos danos causados pela infração, considerando os prejuízos sofridos pelo ofendido" 10 .

É, inquestionavelmente, matéria de caráter civil resolvida pelo juízo criminal, quebrando todas as definições e critérios para a fixação da competência previstas no modelo original adotado pelo sistema processual brasileiro.

E é justamente nessa questão relacionada à matéria que surge o maior problema do art. 387, IV do CPP: que tem legiti-

\footnotetext{
8 Lei $n^{\circ}$. 8.625/93: "Art. $1^{\circ} \mathrm{O}$ Ministério Público é instituição permanente, essencial à função jurisdicional do Estado, incumbindo-Ihe a defesa da ordem jurídica, do regime democrático e dos interesses sociais e individuais indisponíveis."

9 Cf. art. 81, III do Código de Defesa do Consumidor (CDC).

10 Redação dada pela Lei $n^{\circ}$. 11.719/08.
} 
midade para pleitear a verba indenizatória prevista no artigo? $\mathrm{O}$ Ministério Público ou a própria vítima? A seguir, serão tratados alguns elementos para a reflexão acerca do tema.

A ótica do texto, apesar de transdisciplinar, será a do Processo Civil, utilizando-se a sentença penal condenatória e seus efeitos extrapenais, como substrato para a execução civil que visa reparar o dano sofrido pela vítima do crime.

\section{CRITÉRIOS PARA A FIXAÇÃO DA COMPETÊNCIA NO PROCESSO JUDICIAL}

A competência é a aptidão legal para a prática de atos jurisdicionais válidos. É aptidão legal porque está definida em lei. Mesmo quando é possível às partes elegerem o foro competente em contrato, elas não poderão jamais eleger o juiz, sob pena de violação ao princípio do juiz natural. É a lei que estabelece o juízo competente para processar e julgar as causas levadas ao Poder Judiciário.

Competência também é pressuposto processual de validade. Enquanto jurisdição é pressuposto de existência, ou seja, somente haverá processo judicial quando processado perante órgão investido de jurisdição, esse processo somente terá validade quando processado e julgado por órgão jurisdicional competente.

Nesse sentido, Carnelutti conceitua competência como a distribuição do trabalho entre os diversos ofícios judiciais ou entre seus diversos componentes, como requisito de validade do ato processual em que a potestade encontra seu desenvolvimento $^{11}$. É importante salientar que mesmo o ato processual praticado por órgão jurisdicional absolutamente incompetente é capaz de produzir efeitos e, portanto, ser considerado válido ${ }^{12}$.

11 Cf. CARNELUTTI, Francesco. Instituições do Processo Civil, v. 1. Campinas: Servanda, 1999, p. 256.

12 A exemplo do disposto no art. 219 do CPC, fine. 
A competência é atribuída por lei ao órgão judicial, é decorrência direta do princípio da legalidade"13. "A lei processual civil atribui competência aos juízes valendo-se de diferentes 'dados', relacionados principalmente com a própria lide ou com as pessoas litigantes." 14 Se não estiver definida em lei, a competência não existe. Assim, pode existir jurisdição sem competência, mas jamais poderá existir competência sem jurisdição, já que esta pressupõe aquela.

A competência, definida em lei, é classificada consoante critérios. Chiovenda estabeleceu esses critérios que são necessários para a determinação e a classificação da competência, uma vez que os limites da aptidão jurisdicional são prorrogáveis (ou relativos ou dispositivos) ou improrrogáveis (absolutos, necessários), conforme se exijam ou não que sejam observados, e se deixem ou não ao alvedrio das partes ${ }^{15}$. Os critérios de classificação de Chiovenda são utilizados até os dias atuais, e são:

a) Critério objetivo: "ou do valor da causa (competência por valor) ou da natureza da causa (competência por matéria)"16.

O critério objetivo é definido em face da legislação que prevê os casos concretos; que prevê a competência em razão da causa apreciada, seja em razão do seu valor, seja em razão da sua matéria, levando em conta a organização do Poder Judiciário. Não leva em consideração, ao menos primordialmente, a condição especial do órgão julgador, como ocorre com o critério funcional. "O critério objetivo é critério de distribuição das causas entre tribunais de tipo diferente." 17

b) Critério funcional: "extrái-se da natureza especial e das exigências especiais das funções que se chama o magistrado a exercer num processo." 18 Pizzol, sobre o tema, diz que os órgãos

13 Cf. PIZZOL, Patrícia Miranda. A competência no Processo Civil, p. 122.

14 CARNEIRO, Athos Gusmão. Jurisdição e competência, p. 68.

15 Cf. CHIOVENDA, Giuseppe. Instituições de Direito Processual Civil, v. 2: as relações processuais; a relação processual ordinária de cognição. Trad. da 2. ed. italiana por J. Guimarães Menegale. São Paulo: Saraiva, 1943, p. 216.

16 Idem, p. 214 (grifo do autor).

17 CHIOVENDA, Giuseppe. Instituições de Direito Processual Civil, v. 2, p. 215. 18 Idem, p. 214 (grifo do autor). 
jurisdicionais têm sua competência atribuída por lei em vários níveis jurídico-positivos: "Constituição Federal (competência de jurisdição e competência hierárquica dos tribunais superiores); Constituições estaduais (competência originária dos tribunais locais); leis federais (competência territorial) e leis de organização judiciária (competência de juízo e competência interna)."19

O critério funcional leva em conta, para a determinação da competência, a função exercida por cada órgão jurisdicional, consoante o estabelecido, primordialmente, na Constituição Federal e, subsequentemente, nas Constituições Estaduais e demais legislações ordinárias. Como o Brasil é um Estado estabelecido sob um pacto federativo ${ }^{20}$, a hierarquia legal impede a autonomia plena dos entes federados, que devem legislar sempre em consonância com a Constituição Federal. Para manter essa estrutura, incluindo-se o ordenamento jurídico, a organização das funções jurisdicionais se faz necessária; delimitando-se competências especiais consoante as atribuições próprias de cada órgão julgador, ou seja, somente aquele órgão é capaz de julgar aquela espécie de causa. "O critério funcional é critério de distribuição das causas tanto entre tribunais do mesmo tipo, quanto de tipo diferente." 21

c) Critério territorial: sobre esse critério de classificação da competência, Chiovenda diz que "as várias causas da mesma natureza são designadas a juizes do mesmo tipo, com séde, entretanto, em lugares diversos [...]"22. Para que seja estabelecida a comarca competente para julgar determinada causa, ou o território em que será apreciada a demanda, "a designação depende de circunstâncias várias, ou do fato de residir o réu em determinado lugar (forum domicilii, forum rei), ou de haver-se contraído

19 A competência no Processo Civil, p. 122-3.

$20 \mathrm{CF}$ - "Art. $1^{\circ} \mathrm{A}$ República Federativa do Brasil, formada pela união indissolúvel dos Estados e Municípios e do Distrito Federal, constitui-se em Estado Democrático de Direito e tem como fundamentos: [...]"

21 CHIOVENDA, Giuseppe. Instituições de Direito Processual Civil, v. 2, p. 215.

22 Idem, p. 214 (grifo do autor). 
a obrigação em dado lugar (forum contractus), ou de achar-se em dado lugar o objeto da lide (forum rei sitae)."23

O território competente para o julgamento de determinados casos pode ter como origem o interesse público ou a livre convenção das partes, dependendo do caso. "O critério territorial é critério de distribuição das causas entre tribunais do mesmo tipo." 24

Pizzol diz que, "com relação aos critérios, é importante salientar que eles são concorrentes e não excludentes: '[...] não se trata de critérios que se excluam uns aos outros. Todos eles concorrem para a determinação da competência de um órgão judicial'." 25 Aos critérios de Chiovenda, para a classificação da competência, Carneiro acrescenta aqueles que definem a competência como: plena ou cumulativa (quando, em uma comarca, existe somente uma vara, e esta é competente para o julgamento de todas as causas nela propostas); privativa (quando a lei atribui ao órgão julgador o conhecimento apenas de determinadas causas, quer em razão da matéria, quer em razão do valor); comum ou residual (podem ser exclusivas ou concorrentes, consoante possam ou não ser eleitas pelo autor da ação); originária e recursal (consoante a instância) ${ }^{26}$. Esse trabalho ficará restrito às classificações de competência mais abrangentes.

\subsection{Competência absoluta e relativa}

A primeira classificação da competência ora abordada será aquela que leva em consideração o interesse (público ou da parte) e a possibilidade ou não de eleição de foro, prorrogação ou modificação da competência. São os gêneros da competência segundo os quais todas as demais classificações serão determinadas.

23 Idem, pp. 214-5 (grifo do autor).

24 CHIOVENDA, Giuseppe. Instituições de Direito Processual Civil, v. 2, p. 215.

25 A competência no Processo Civil, pp. 144-5.

26 Cf. Jurisdição e competência, pp. 116-9. 
A administração da justiça é interesse público. A escolha do órgão julgador pelas partes por meio de eleição prévia somente poderá ocorrer nos casos em que a lei possibilite, sem existir, contudo, residualidade em relação aos demais casos, ou seja, não se excluem critérios de classificação da competência para se determinar a possibilidade de escolha dos outros. Mas o legislador deu certa margem ao autor da demanda para escolher o foro, ou para as partes de um negócio jurídico elegerem o órgão jurisdicional que irá dirimir eventuais conflitos resultantes do acordo ou contrato.

A competência absoluta é aquela determinada pelo interesse público, resultante de norma cogente que vincula obrigatoriamente as partes e o órgão jurisdicional. Não está sujeita aos critérios de modificação ou prorrogação de competência, o que significa dizer que ou o juízo é absolutamente competente, ou absolutamente incompetente.

A competência relativa, por sua vez, é determinada pela lei, porém com certa flexibilidade, pois pode ser eleita pelas partes anteriormente à propositura da demanda e pode ser prorrogada; enfim, é passível de se adequar à comodidade das partes ou a acontecimentos supervenientes à propositura da ação, como a conexão ou a continência, por exemplo ${ }^{27}$.

A incompetência relativa deverá ser sempre suscitada pela parte por meio de exceção ${ }^{28}$, não podendo, sob hipótese alguma, ser declarada de ofício pelo juízo ${ }^{29}$, exceto se necessária a declaração de nulidade da cláusula de eleição de foro em contrato de adesão. Nesse caso, porém, a manifestação do órgão jurisdiconal ocorre em face do contrato leonino, abusivo, e não em face da declaração de incompetência, especificamente.

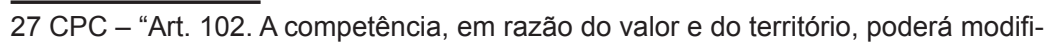
car-se pela conexão ou continência, observado o disposto nos artigos seguintes." 28 CPC - "Art. 112. Argúi-se, por meio de exceção, a incompetência relativa. Parágrafo único. A nulidade da cláusula de eleição de foro, em contrato de adesão, pode ser declarada de ofício pelo juiz, que declinará de competência para o juízo de domicílio do réu."

29 BRASIL. Superior Tribunal de Justiça.Súmula 33: A incompetência relativa não pode ser declarada de ofício. 
A incompetência torna-se, nesses casos, uma consequência do ato jurisdicional, e não o objeto do próprio ato ${ }^{30}$.

Dois critérios, portanto, são predominantes na classificação da competência em absoluta ou relativa: o interesse (público ou das partes) e a possibilidade, ou não, da sua modificação (como ocorre na prorrogação e na reunião dos processos por conexão ou continência).

\subsection{A competência em razão da matéria}

Após a classificação da competência em absoluta e relativa, que é a classificação mais abrangente e, portanto, parâmetro para as demais classificações, é importante a apresentação da classificação que utiliza a matéria para a definição da competência. $\mathrm{O}$ critério leva em consideração o direito material posto em causa, se cível, penal ou trabalhista.

Chiovenda denomina essa classificação como "competência determinada pela natureza da causa" 31 , pois "é determinada de acordo com o pedido formulado pelo autor (que é qualificado pela causa de pedir)." 32 É a matéria em litígio (isto é, a natureza do direito material controvertido) que servirá, inicialmente, para determinar a competência civil esfera constitucional, atribuindo a causa à Justiça Federal ou à Justiça local ${ }^{33}$.

Passada essa fase, o órgão judicante competente será determinado consoante o critério territorial, sendo possível, dentro do mesmo foro, a subdivisão de varas especializadas (por exemplo: varas de família, do Tribunal do Júri, de falência, de direito bancário, etc.). No mesmo sentido, Carneiro diz que "no âmbito da Justiça comum e em primeiro grau de jurisdição, são criadas, em comarcas de intenso movimento forense, varas priva-

30 Cf. art. 112, parágrafo único do CPC.

31 Cf. Instituições de Direito Processual Civil, v. 2, p. 247.

32 PIZZOL, Patrícia Miranda. A competência no Processo Civil, p. 213.

33 Cf. art. 109 da CRFB 
tivas em razão da matéria, em face das vantagens de uma maior especialização dos juízos." 34

A competência em razão da matéria é absoluta e, portanto, indisponível e improrrogável. ${ }^{35}$ Também a Constituição Federal, as Constituições Estaduais, as leis federais e as leis de organização judiciária fazem remissão à competência em razão da matéria.

Porém o legislador, ao criar a redação do inciso IV do art. 387 do CPC, através da Lei $\mathrm{n}^{\circ}$. 11.719/08, acrescentou uma flexibilização a este critério de classificação de competência. Ao juízo criminal é permitido julgar matéria civil, relacionada à indenização sofrida pela vítima do fato criminoso, a qual consistirá em "valor mínimo para reparação dos danos causados pela infração, considerando os prejuízos sofridos pelo ofendido”.

Não se duvida da capacidade do juiz criminal em proferir sentença que traga tal matéria não usual à sua praxe. $O$ problema surge no processamento da causa, pois o processo crime se presta, primordialmente, para a apuração da materialidade e da autoria dos crimes, e não da extensão dos danos indenizáveis sofridos pela vítima.

\section{RESPONSABILIDADE CIVIL POR ATO CRIMINOSO}

O direito civil brasileiro, através da responsabilidade civil, trata da reparação do dano causada por ato ilícito ${ }^{36}$. O agente que pratica um ato ilícito de ordem civil fica obrigado a reparar o dano causado, desde que presentes a conduta, o nexo causal e o dano propriamente dito, que poderá ser de ordem material ou moral ${ }^{37}$.

Responsabilidade é substantivo derivado de responder; responder pelo ato praticado. Porém, é de se frisar que o ato

34 Jurisdição e competência, p. 237 (grifo do autor).

35 Cf. CARNEIRO, Athos Gusmão. Jurisdição e competência, p. 238; PIZZOL,

Patrícia Miranda. A competência no Processo Civil, p. 213.

36 Cf. art. 927 do CC.

37 Sobre o dano moral, a CRFB trouxe expresso o dever de repará-lo no art. $5^{\circ}, \mathrm{V}$ eX. 
ilícito civil tem um viés diferente do penal e, exatamente por isso, "a responsabilidade civil é independente da criminal, não se podendo questionar mais sobre a existência do fato, ou sobre quem seja o seu autor, quando estas questões se acharem decididas no juízo criminal" 38 .

Com base em tal premissa legal, o ilícito civil pode ser uma consequência do ilícito penal ou não. Será ato ilícito civil puro quando a conduta for capaz de causar dano a outrem, seja por ato comissivo, omissivo ou por abuso de direito ${ }^{39}$. Será ato ilícito derivado do crime quando a conduta constituir fato típico, antijurídico e culpável, deixando resultados de ordem material ou não.

Existem, assim, crimes formais, que não deixam resultados materiais. Mas podem resultar em dano moral, como nos casos de crimes de concussão ${ }^{40}$. E existem crimes materiais, que deixam resultados materiais e, dentre eles, o dano material da vítima pode estar enquadrado no resultado, como, por exemplo, o furto ${ }^{41}$.

Nesses casos, o crime pode ser apurado junto ao juízo criminal enquanto, simultaneamente, a indenização da vítima é apurada junto ao juízo cível. Nesses casos de tramitação simultânea dos processos cível e criminal relativos ao mesmo fato ilícito, é faculdade do juiz cível sobrestar o processo até que o juízo criminal apure a materialidade e autoria. Assim, evita-se a contradição de julgados, cabendo ao cível acatar o decidido pelo crime. Mas, caso o processo criminal não seja instaurado em 30 dias do sobrestamento, o juízo cível dará continuidade ao processo $^{42}$.

No processo criminal, tanto a sentença condenatória como a absolutória podem reconhecer a materialidade e autoria

38 Art. 932 do CC, verbis.

39 Cf. arts. 186 e 187 do CC.

$40 \mathrm{CP}$ - Art. 316 - Exigir, para si ou para outrem, direta ou indiretamente, ainda que fora da função ou antes de assumi-la, mas em razão dela, vantagem indevida:

Pena - reclusão, de dois a oito anos, e multa.

41 CP - Art. 155 - Subtrair, para si ou para outrem, coisa alheia móvel:

Pena - reclusão, de um a quatro anos, e multa.

42 Cf. art. 110 do CPC. 
do crime, pois o réu responde perante o Estado e poderá ser reconhecida a existência de alguma excludente de ilicitude ou, mesmo, causa extintiva de punibilidade.

Transitada em julgado a sentença penal condena-
tória, não se admite no juízo cível a rediscussão da
responsabilidade pelo ato ilícito. Portanto, não é
viável a rediscussão da culpa ou do nexo causal,
limitando-se a cognição judicial a aspectos da
própria execução ou ao valor do dano a ser ressar-
cido. $^{43}$

A sentença penal condenatória transitada em julgado constitui título executivo judicial que habilita a vítima a executá-la junto ao juízo cível, buscando, assim, a reparação pelo dano sofrido com o crime ${ }^{44}$. Conforme a modalidade de ação penal, a participação da vítima pode ser maior ou menor.

\section{AÇÕES PENAIS}

A ação penal visa apurar fato criminoso e, em consequência, a aplicação da pena ao condenado. Existe uma preocupação especial no Direito Penal com a ressocialização do criminoso condenado, o que o difere em especial do Direito Civil, que busca a reparação do dano sofrido pela vítima. Nesse sentido, dependendo da modalidade de crime praticado, a participação da vítima no processo criminal pode passar de um simples elemento de prova à própria legitimada para a sua propositura.

As ações penais públicas incondicionadas constituem a regra geral. As ações penais privadas e as ações penais públicas condicionadas, as exceções que devem estar previstas em $l \mathrm{ei}^{45}$. As ações penais públicas incondicionadas têm como peça inaugural a denúncia promovida pelo Ministério Público, ao passo que a condicionada depende de representação do ofendido ou

43 MARINONI, Luiz Guilherme e ARENHARDT, Sérgio Cruz. Curso de Processo

Civil - Execução. 2. ed. São Paulo: RT, 2008, p. 415.

44 Cf. art. 475-N, II do CPC.

45 Cf. art. 100, caput do CP. 
requisição do Ministro da Justiça. As ações penais privadas se processam mediante queixa-crime do ofendido.

Constituem princípios informadores da ação penal pública incondicionada:

1) Oficialidade - o Ministério Público é o órgão incumbido de promover a ação penal, devendo fazê-lo de ofício, ou seja, por iniciativa própria.

2) Indisponibilidade - O Ministério Público, como titular da ação penal, poderá intentá-la e acompanhá-la em todos os seus trâmites legais. Não poderá, entretanto, dela dispor, declinando do seu exercício, transigindo, desistindo e acordando.

3) Obrigatoriedade ou legalidade - o Ministério Público, presentes os elementos que autorizam a propositura da ação penal, deverá fazê-lo [...] de forma totalmente independente, sem sofrer qualquer ingerência [de outros poderes do Estado ou privados].

4) Indivisibilidade - [...] o Ministério Público haverá de proceder contra todos os autores e partícipes da infração criminal. ${ }^{46}$

As ações penais privadas, por sua vez, são disponíveis, pois constituem crimes que não configuram interesse público, mas, somente, da vítima. Pode ela, portanto, desistir da ação penal ou mesmo transigir conforme a sua conveniência. Pode-se considerar, inclusive, o perdão do ofendido, que tem o condão de obstar a propositura da queixa-crime ${ }^{47}$.

A ação penal se baseia, especialmente, nas provas coletadas através de Inquérito Policial, que servem como base para a descrição do fato criminoso, do qual o réu irá se defender no processo.

46 COSTA Jr.. Paulo José da. Curso de Direito Penal. 9. ed. São Paulo: Saraiva, 2008, pp. 261-2.

47 Art. 105 do CP. 


\section{O INQUÉRITO POLICIAL E A PARTICIPAÇÃO DA VÍTIMA}

No Inquérito Policial as provas que embasarão a denúncia ou a queixa serão apuradas através de perícia técnica ou oitiva de depoentes. $\mathrm{O}$ ofendido poderá requerer qualquer diligência à autoridade policial através do juiz criminal, o que demonstra, de per si, a ausência de disponibilidade da ação penal à vítima, nesses $\operatorname{casos}^{48}$.

Em um conceito mais específico, o Inquérito Policial

é o conjunto de diligências realizadas pela polícia judiciária para a apuração de uma infração penal e de sua autoria, a fim de que o titular da ação penal possa ingressar em juízo (CPP, art. 4º). Trata-se de procedimento persecutório de caráter administrativo instaurado pela autoridade policial. Tem como destinatários imediatos o Ministério Público, titula exclusivo da ação penal pública (CF, art. 129, I), e o ofendido, titular da ação penal privada (CPP, art. 30); como destinatário mediato tem o juiz, que se utilizará dos elementos de informação nele constantes, para o recebimento da peça inicial e para a formação de seu convencimento quanto à necessidade de decretação de medidas cautelares. ${ }^{49}$

É, portanto, de caráter administrativo, o que faz com que as provas nele produzidas devam ser judicializadas, ratificadas ou reproduzidas pelo juízo criminal. $\mathrm{O}$ juízo criminal, então, realizará as determinações concernentes à matéria criminal, não lhe cabendo, por força da competência, mandar à autoridade policial que proceda à apuração da extensão do dano sofrido pela vítima, exceto se esta estiver direta e imediatamente ligada à materialidade do crime.

48 Art. 12 e ss. do CPP.

49 CAPEZ, Fernando. Curso de Processo Penal. 6. ed. São Paulo: Saraiva, 2001, p. 64. 


\section{A DENÚNCIA}

Consoante já exposto, a denúncia, oferecida pelo Ministério Público, constitui a peça inaugural da ação penal pública. Nela, o Ministério Público representa o Estado, o interesse público, a coletividade atingida pela ação criminosa. Busca, assim, a harmonização da sociedade através da aplicação da pena ao criminoso. Como expresso no art. 127 da CRFB, a "defesa da ordem jurídica, do regime democrático e dos interesses sociais e individuais indisponíveis"

Os elementos da denúncia, que a compõem, são um reflexo dessa máxima, como dispõe o art. 41 do CPP: "A denúncia ou queixa conterá a exposição do fato criminoso, com todas as suas circunstâncias, a qualificação do acusado ou esclarecimentos pelos quais se possa identificá-lo, a classificação do crime e, quando necessário, o rol das testemunhas."

As circunstâncias do fato criminoso, expostas na denúncia, dizem respeito à causalidade, aos elementos que compõem o cenário do crime, e não aos danos sofridos pela vítima. Como dito anteriormente, estes podem muito bem estar enquadrados na materialidade do crime, mas podem, por vezes, ser muito mais abrangentes, constituindo lucros cessantes, perda de uma chance ou toda e qualquer modalidade de danos que se prolongam no tempo, indo além do momento do crime.

O Ministério Público sequer possui legitimidade para buscar a reparação civil da vítima, pois, como exposto, a Lei Orgânica prevê a sua atuação como custos legis (fiscal da lei) ou como representante extraordinário, de causas que envolvem incapazes ou direitos transindividuais. A denúncia, portanto, decorre de representação extraordinária do Estado, da sociedade como um todo, da busca pela manutenção da ordem pública, dos direitos sociais. O Ministério Público não tem legitimidade para postular direitos patrimoniais privados de caráter individual, à exceção do já demonstrado direito de incapazes. 


\section{EFEITO EXTRAPENAL DA SENTENÇA PROFERIDA PELO JUÍZO CRIMINAL}

A sentença penal condenatória tem o condão de tornar certa a obrigação de indenizar. A certeza, frise-se, é um dos requisitos da obrigação para a sua execução no juízo cível, a teor do disposto nos arts. 580 e 586 do CPC. Tendo certeza, caberá à vítima buscar a liquidez, que constitui o valor da indenização, e aguardar a exigibilidade, que se dá em 15 dias a partir da decisão que julgar a liquidação ${ }^{50}$.

Sobre o efeito extrapenal da ação penal condenatória, "trata-se de efeito automático, que não necessita ser expressamente pronunciado pelo juiz na sentença condenatória e destina-se a formar título executivo judicial para a propositura de ação civil ex delicto" ${ }^{51}$. No caso da execução direta no cível, a vítima poderá executar a parte líquida, se houver, enquanto, simultaneamente, liquida a ilíquida ${ }^{52}$. Da sentença penal condenatória "[...] nascem duas ações diferentes: a ação penal, cujo titular é o Ministério Público; e a ação civil reparatória ex delicto, que incumbe à vítima do dano." ${ }^{53}$

Existe, assim, a possibilidade de o juiz criminal trazer, em sua sentença condenatória, um valor indenizatório a ser pago pelo criminoso à vítima do ato.

\section{A CONDENAÇÃO DE MATÉRIA CIVIL NA SENTENÇA PENAL CONDENATÓRIA}

Com o advento da redação do inciso IV do art. 387 do CPP, coube ao juiz criminal inserir, no bojo do dispositivo da sentença, um mínimo indenizatório a ser pago pelo criminoso à vítima. Justamente por se tratar de matéria alienígena ao juízo criminal, o quantum previsto na sentença penal condenatória

50 Art. 475-J do CPC.

$51 \mathrm{NUCCl}$, Guilherme de Souza. Código Penal Comentado. 3. ed. São Paulo: RT, 2003 , p. 321.

52 Art. $475-I, \S 1^{\circ}$ do CPC.

53 ASSIS, Araken de. Manual da Execução. 12. ed. São Paulo: RT, 2009, p. 171. 
constituirá uma faculdade e um piso, um mínimo que terá o escopo de não deixar a vítima imediatamente desamparada enquanto discute o montante total da sua indenização.
A sentença penal condenatória dotada de seme- lhante efeito é a definitiva, transitada em julgado - não existe execução provisória -, e submetida, obrigatoriamente, ao procedimento de liquidação (art. 475-A do CPC), exceto no que respeita ao valor fixado no próprio ato a título de perdas e danos (art. 63, parágrafo único, do CPP, c/c art. 387, IV, do CPP). Não se pode supor, ante o prin- cípio da separação, que o juiz penal haja liquidado, senão de modo parcial, a obrigação de reparar o dano civil. Aliás, há até citação pessoal na liqui- dação, ou na execução da parte líquida (art. 475-N, parágrafo único), formando-se "novo" processo. Na liquidação, notou Ovídio A. Baptista da Silva, magistralmente, às vezes afloram questões inaten- diveis em sede penal e, contudo, relevantes no âmbito da ação reparatória. Dentre elas se destaca a participação da vítima no resultado, comumente chamada de "culpa concorrente". É o momento de considerá-la, sem o mínimo atentado à indis- cutibilidade do efeito anexo, pois dito elemento concerne à quantificação do dano..$^{54}$

Caberá, portanto, ao juízo cível apurar a extensão total do dano sofrido pela vítima que ultrapasse o piso disposto na sentença criminal através de liquidação de sentença. Assis, porém, equivoca-se ao dizer que não existe execução provisória de sentença penal condenatória transitada em julgado. Não existe, por óbvio, nos termos do art. 475-I, § 20 do CPC; mas existe nos termos do art. 475-M, § 1० do mesmo diploma legal, que permite a execução mediante caução quando o juiz atribuir efeito suspensivo à impugnação ao cumprimento da sentença.

O próprio juízo criminal não tem estrutura para apurar, no processo, todos os danos sofridos pela vítima. Qualquer

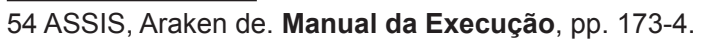


elemento que determine a aceitação pela vítima do valor disposto na sentença penal condenatória como total reparador do dano sofrido violaria em absoluto o princípio constitucional da ampla defesa, haja vista a impotência do ofendido perante a condução do processo criminal, em especial a produção das provas que lastreiam seu direito patrimonial privado ${ }^{55}$.

\section{CONCLUSÃO}

A intenção do legislador ao criar a redação do inciso IV do art. 387 do CPP pode ter sido das melhores, afinal, para a reparação do dano sofrido por ato criminoso mesmo o único imóvel residencial da entidade familiar do condenado é penhorável ${ }^{56}$. Mas de nada adianta tal previsão legal se a reparação vem tardia, mesmo porque qualquer desfazimento de bens pelo criminoso na fase de liquidação de sentença não constitui fraude à execução, nos termos previstos no art. 593 do CPC.

Ademais, a razoável duração do processo, prevista expressamente no inciso LXXVIII do art. $5^{\circ}$. da CRFB, faz com que a demora ocasionada pelo processo na obtenção do bem da vida constitua violação direta a direito fundamental. Os mecanismos processuais, entre eles os já mencionados arts. 387, IV do CPP e 475-I, § 1 o do CPC, buscam dar efetividade à tutela condenatória, permitindo à vítima penhorar bens do réu em razão da tutela executiva enquanto, simultaneamente, busca a liquidação do saldo remanescente.

Mas, atualmente, alguns tribunais têm interpretado essa sistemática de modo pouco proveitoso para o processo. Inicialmente, o Superior Tribunal de Justiça fixou o entendimento de que é impossível a concessão do piso indenizatório de ofício

\footnotetext{
55 Nesse sentido, a $6^{\text {a }}$ Turma do STJ decidiu que "Inexistindo nos autos elementos que permitam a fixação do valor, mesmo que mínimo, para reparação dos danos causados pela infração, o pedido de indenização civil não pode prosperar, sob pena de cerceamento de defesa" (REsp 1176708 / RS. Rel. Min. Sebastião Reis Júnior. DJe 20.06.2012).

56 Cf. art. $3^{\circ}$, VI da Lei $n^{\circ}$. 9.099/90 - Lei do Bem de Família.
} 
pelo magistrado, devendo haver requerimento expresso pelo ofendido para tal. Considerando o princípio processual da congruência que vincula a tutela jurisdicional ao pedido (arts. 128 e 460 do CPC), o Tribunal tem razão. Segue parte do voto do eminente relator:

Isso estabelecido, a permissão legal de cumulação de pretensão acusatória com a de natureza indenizatória não dispensa a existência de expresso pedido formulado pelo ofendido, dada a natureza privada e exclusiva da vítima daquela pretensão. Além disso, deve haver a participação do réu, sob pena de frontal violação ao seu direito de contraditório e ampla defesa, na medida em que o autor da infração faz jus à manifestação sobre a pretensão indenizatória e seu quantum, que, se procedente, pesará em seu desfavor.

Portanto, o legítimo exercício da pretensão indenizatória reclama a verificação da presença das condições da ação e dos pressupostos processuais.

A fixação de indenização sem o correspondente pedido implica violação ao princípio da correlação, incidente sobre os processos cíveis e penais.

(REsp 1236070 / RS. STJ, 5a Turma, Rel. Min. Marco Aurélio Bellizze. Dje 11.05.2012)

Apesar de corretíssima a preocupação com a garantia à ampla defesa e ao contraditório, surge a questão principal: nos crimes de ação penal pública, como pode o ofendido realizar o pedido indenizatório? A peça inaugural da ação criminal é a denúncia do Ministério Público, não existindo qualquer possibilidade de o ofendido adita-la ou emenda-la. É requisito impossível sob a ótica do Processo Penal, e imprescindível sob a do Processo Civil.

Talvez essa simbiose entre matérias seja o causador principal da confusão aventada. O Tribunal de Justiça do Estado de Santa Catarina vai além, determinando que haja pedido formal do ofendido no sentido de haver as perdas e danos, ou do Minis- 
tério Público, para que o magistrado possa aplicar a condenação mínima do art. 387, IV do CPP57.

Conforme já demonstrado, é ilícito e inconstitucional ao Ministério Público agir na defesa de direitos patrimoniais privados, à exceção das causas que versem sobre direitos transindividuais ou de incapazes. Não pode, sob pena de ofensa à CRFB, o MP pedir, na denúncia, a reparação da vítima pelos danos que sofrera em razão do ato criminoso.

A interpretação dos tribunais cria um obstáculo intransponível à vítima: o de ter o direito à indenização, mas ter tolhidas as ferramentas para obter o bem da vida em um prazo razoável.

Será ela obrigada a aguardar e aguardar. Primeiro, o decurso da ação penal até o seu trânsito em julgado. Em seguida, o decurso da liquidação de sentença, que poderá muito bem ser por artigos, o que constituirá novo processo de cognição plenária. A seguir, e somente a seguir, poderá buscar a tão sonhada reparação do dano sofrido - o bem da vida -, se o criminoso, já condenado, ainda possuir algum patrimônio passível de execução.

Não bastam ferramentas. Não basta boa intenção. O legislador parece não prever sistematicamente como a sua obra será aplicada na prática e, nesse sentido, não parece haver saída ou solução adequada.

Abstract: The prosecution has the main scope of the punishment agent who practices a crime. For punishment the law provides for the deprivation of liberty, the restriction of rights and fines, all completed before the state. Repair or compensation for the harm suffered by the victim is a side effect of criminal conviction, which allows you to no longer discuss this right, but directly run your credit in the face of the condemned. The participation of victims in criminal proceedings, however, is minimal, summing up the testimony. She has

57 Apelação Criminal n. 2010.074356-5, de Criciúma, rel. Des. Alexandre d'Ivanenko, j. em 22.03.2011. 
no room to apply the sentencing of the defendant to indemnify him and even fewer produce evidence relating to the extent of the damage. Based on these problems, the direct execution of the criminal sentence has become final without the need for prior settlement in civil court, it becomes increasingly difficult to achieve. Perhaps impossible.

Keywords: Liability. Damages. Penal sentence

\section{REFERÊNCIAS}

ASSIS, Araken de. Manual da Execução. 12. ed. São Paulo: RT, 2009.

BONAVIDES, Paulo. Curso de Direito Constitucional. 13. ed. 2. tiragem. São Paulo: Malheiros, 2003

CARNELUTTI, Francesco. Instituições do Processo Civil, v. 1. Campinas: Servanda, 1999.

CAPEZ, Fernando. Curso de Processo Penal. 6. ed. São Paulo: Saraiva, 2001.

CARNEIRO, Athos Gusmão. Jurisdição e competência. 14. ed. Atualizada, inclusive em face da Emenda Constitucional n. 45/2004, São Paulo: Saraiva, 2005.

CHIOVENDA, Giuseppe. Instituições de Direito Processual Civil, v. 2: as relações processuais; a relação processual ordinária de cognição. Trad. da 2. ed. italiana por J. Guimarães Menegale. São Paulo: Saraiva, 1943.

COSTA Jr.. Paulo José da. Curso de Direito Penal. 9. ed. São Paulo: Saraiva, 2008.

MARINONI, Luiz Guilherme e ARENHARDT, Sérgio Cruz. Curso de Processo Civil - Execução. 2. ed. São Paulo: RT, 2008.

NUCCI, Guilherme de Souza. Código Penal Comentado. 3. ed. São Paulo: RT, 2003.

PIZZOL, Patrícia Miranda. A competência no processo civil. Coleção estudos de direito de processo Enrico Túlio Liebman - v. 55. São Paulo: RT, 2003. 